\title{
Advances in Knowledge of Androgens: How Intentional and Accidental Neurosteroid Changes Inform Us of Their Action and Role
}

\author{
Cheryl A. Frye ${ }^{1,2,3,4,5,6} \cdot$ Dan DaCosta $^{2} \cdot$ Vincenzo F. Lembo ${ }^{6,7} \cdot$ Alicia A. Walf $^{3,8}$
}

Accepted: 18 August 2020 / Published online: 16 December 2020

(C) The Author(s) 2020

\begin{abstract}
Purpose of Review Here, we summarize current knowledge of androgens' action gained over the recent years.

Recent Findings Neurosteroids are produced in the brain and peripheral nerves, independent of endocrine glands have been investigated for how they are regulated, and have actions via non-steroid receptor targets to mediate social, affective, and cognitive behavior and to protect the brain. Androgens' organizing actions in the peri-natal period have effects throughout the lifetime that may be recapitulated later in life during critical periods and at times of challenge. Developmental changes in androgens occur during mid-childhood, adrenarche, puberty, adolescence, young adulthood, middle age, and andropause. Changes in androgens with a $5 \alpha$-reductase inhibitor, such as finasteride, result in disruptions in organizational and activational functions of androgens that can be unremitting.

Summary Normal developmental or perturbation in androgens through other means can cause changes in androgen-sensitive phenotypes throughout the lifespan, in part through actions of neurosteroids.
\end{abstract}

This article is part of the Topical Collection on Preclinical and Psychophysiology

\section{Highlights}

- Androgens have perinatal effects to masculinize and defeminize individuals; some of these organizing effects of androgens may occur at other key critical periods.

- Finasteride has the capacity to interfere with many downstream or alternative pathways for production, metabolism, or actions of (neuro) steroids and can produce psychopathologies that are unremitting in some individuals.

- Shunting one pathway increases activity of other enzymes to increase or decrease neurosteroids, which have many .effects and may occur as a result of interference with the brain through environmental exposures (endocrine disruptors), pharmacological exposures (finasterides), or accidents such as Traumatic Brain Injury (TBI).

Cheryl A. Frye

cafrye@albany.edu

1 Department of Psychology, State University of New YorkUniversity at Albany, 1400 Washington Avenue, Albany, NY 12222, USA

2 Department of Biology, State University of New York- University at Albany, 1400 Washington Avenue, Albany, NY 12222, USA

3 Centers for Life Sciences, State University of New York- University at Albany, 1400 Washington Avenue, Albany, NY 12222, USA
4 Neuroscience Research, State University of New York- University at Albany, 1400 Washington Avenue, Albany, NY 12222, USA

5 Alaska INBRE Program University of Alaska, 108 Irving building (UAF), Fairbanks, AK 99775-7040, USA

6 Comprehensive Neuropsychological Services, 490 Western Avenue, Albany, NY 12203, USA

7 Denali Wellness Center, 46 Colonial Avenue Suite A, Albany, NY 12203, USA

8 Rensselaer Polytechnic Institute Department of Cognitive Sciences, 110 Eighth Street, Troy, NY 12180, USA 
Keywords Androgens $\cdot$ Neurosteroids $\cdot 3 \alpha$-Androstanediol $\cdot$ Finasteride $\cdot$ Post-finasteride syndrome $\cdot$ Traumatic brain injury

\section{Introduction}

The purpose of this paper is to provide an update on various mechanisms of androgens that have bearing on their effects on stress, sex, and other important functions. First, an overview of neurosteroids' action will be discussed, then the relevance for masculinization and feminization, and developmental changes in androgens. Second, how finasteride can induce feminization and demasculinization is discussed, then its effects on androgens, neurosteroids, and the brain; direct effects on T and DHT, and 5a-reductase expression and distribution; and neuroendocrine effects of post-finasteride syndrome, neurosteroids, and receptor targets, including GABA, dopamine, glutamate, glycine, ER $\beta$ receptors, and genetic targets. Third, the clinical effects of post-finasteride syndrome and physical, cognitive, emotional, and sexual function will be discussed and compared with the effects of mild traumatic brain injury. Our hypothesis is that many of the substrates that underlie mild traumatic brain injury may be analogous to pathological effects of finasteride.

\section{Overview of Neurosteroid Action in the Brain}

Now, it is generally accepted that cholesterol-based, steroid hormones can be produced outside of traditional steroid organs (gonads, adrenals, placenta) in the brain and peripheral nerves (termed neurosteroids) [1]. Neurosteroids influence autonomic function (hindbrain), reward (midbrain), emotions (limbic system), learning (hippocampus, cerebellum), executive function (prefrontal cortex), and procedural memory (cerebellum). The biosynthetic pathway for neurosteroid production involves the $18 \mathrm{kDA}$ translocator protein (TSPO) and steroidogenic acute regulatory (StAR) proteins which transport cholesterol into the mitochondria. Pregnane $\mathrm{X}$ receptor (PXR) homeostatically regulates cholesterol biosynthesis and cytochrome P450-dependent C27 side chain cleavage enzymes (P450scc). $3 \beta$ - and 3a-hydroxysteroid dehydrogenases ( $3 \beta a-H S D)$ and $5 a-$-reductase (5a-R) are oxidized by P450scc to form pregnanolone, which is then metabolized by $3 \beta$-HSD to progesterone, which then can be metabolized to form testosterone (T). A pathway to form 3a-androstanediol (3a-diol) from $\mathrm{T}$ involves sequential actions of $5 \mathrm{a}-\mathrm{R}$, an irreversible action that forms dihydrotestosterone (DHT), and then 3adiol. These steroidogenic factors are expressed in the spinal cord, cerebellum, pons, medulla, ventral tegmentum, prefrontal cortex, hippocampus, basal ganglia, hypothalamus, and thalamus, in an age-, sex-, and hormone-dependent manner [2-4], as early as prenatal day 7 , which imply their critical role in function.
Androgens, and their synthetic variants (selective androgen receptor modulators (SARMs)), have varied actions through androgen receptors (ARs). DHT has a tenfold greater potency of inducing AR signaling than T [5]. 3a-diol and $3 \beta$-diol, unlike T and DHT, do not have actions via ARs. Instead, 3a-diol has affinity for neurotransmitter targets, such as gamma-aminobutyric acid $(\mathrm{GABA})_{\mathrm{A}}$ receptors [6, 7]. 3a-diol and $3 \beta$-diol have affinity for estrogen-receptor $(\operatorname{ER} \beta)$ [8] to mediate behavioral and physiological effects of androgens [9-12]. Androgens can also have actions through dopamine pathways involved in movement, reward, and motivation [9-14•]. Humans and animals will work to get access to androgens, an effect that is dampened with naloxone [10]. Androgens will condition a place preference [15]. The pattern of these effects in humans has been modeled in rodents [16, 17]. It is notable that some neurodevelopmental (e.g., autism spectrum disorders), neuropsychiatric [18], and neurodegenerative (i.e., Alzheimer's, all-cause dementia, and seizure) [19-24] disorders are associated with differences in androgen levels. We will discuss these findings in the context of recent progress made by our research lab, clinic, and others.

\section{Mechanisms of Masculinization and Feminization in Males}

Androgens have well-known pleiotropic effects to regulate growth and functional aspects of the reproductive, central nervous, skeletal, and cardiovascular systems throughout the lifespan. However, these robust actions of androgens occur much earlier in development when we consider sexual differentiation. The presence of androgens typically early in development results in pervasive effects throughout the lifespan on the typical pattern of androgen secretion. Supported by early investigations in the field [25], the capacity of androgens that are secreted from the testes during early pre- or peri-natal development is thought to "organize" the central nervous system, including the neural control of post-pubertal patterns of androgen release, as well as the sensitivity of specific brain structures to androgens later in life for behaviors. We call this patterning of androgen secretion early on that organizes later adult responses as sexual differentiation.

\section{Sexual Organization}

Genetics Becoming a male or a female mammal depends upon the development of many different types of sexual characteristics/features: chromosomal, genetic, gonadal, hormonal, and behavioral. Sex determination begins this process; that is, the 
presence of the $\mathrm{Y}$ chromosome after conception has the individual develop as a male (i.e., genetic sex). In this, the genetic sex related to the sry gene on the Y chromosome becomes active and starts the development of the testes from the primordial, undifferentiated gonads. When the testes develop, hormonal sex develops. Specifically, from the testes, T and anti-Müllerian hormone are secreted, which actively suppresses the female phenotype (defeminization). Testosterone and its metabolites are important for masculinization even at this early stage of development. Anti-Müllerian hormones inhibit the female typical pathway of development (defeminizing effects). These hormones in males in utero then begin to have actions on the body and brain during development, which ends up leading to behavioral sex/gender differences later on. In XX individuals, genetic females, the lack of sry begets the lack of testes and hormones from it; the Müllerian system develops as does the internal and external female genitalia and the brain. These are considered both feminizing and demasculinizing effects. In early development, without the presence of androgens, the female phenotype develops; however, this can also happen when there are deficits in androgen metabolism or with actions of androgens at targets, such as ARs early on.

\section{Methods for Studying Androgens}

The classic approach in behavioral neuroendocrinology is to determine the role of a hormone for a behavioral process by assessing endogenous changes in the hormone, extirpation of the hormone (i.e., removal of the gonads), and replacement back of the hormone. Endogenous changes are used to assess the extent to which levels of the hormone in question vary with the behavioral endpoint of interest. This is usually assessed in males by investigating behaviors and androgens that vary (1) from females (which typically have lower levels of androgens), (2) by season (e.g., seasonal breeders), and (3) across the lifespan (post-pubertal, with androgen decline in advanced aging).

Changes Across the Lifespan Many of the targets of androgens have been highlighted by changes in the tissues' functions with alterations in androgens across time. At puberty, $\mathrm{T}$ is important for enlargement of vocal cords, penis, and scrotum; changes in musculature; and initiation of spermatogenesis. At puberty, DHT is involved in growth of facial and body hair. Later in life, DHT is important for male pattern baldness (MPB) and disorders of the prostate, such as benign prostate hyperplasia (BPH) and prostate cancer. At puberty, androgen levels increase and remain high until midlife when androgen levels begin to decline. In humans, this is often assessed by determining age-related changes in function. Unlike the precipitous decline in ovarian function with reproductive senescence that is observed among women, men experience a decade-by-decade decline in androgens. This decline is often termed "andropause" and, although the nature of the decline in steroids is different from that observed during the menopause of women, both situations have clear symptomology associated with steroid decline. For example, decline in bioactive androgens in men with aging is associated with diminished libido, fatigue, decreased muscle mass, osteoporosis, depression, anxiety, and/or cognitive dysfunctions.

Aging men can experience decline in gonadal, sexual, cognitive, and affective function and the role and mechanisms of androgens for these effects have been studied extensively. Androgen levels begin to rise after puberty and remain high until midlife [26], when a decade-by-decade decline in endogenous androgen levels occurs among men [27]. On average, this decline involves an annual $0.4 \%$ reduction in total $\mathrm{T}$ and a $1.2 \%$ reduction in biologically free $\mathrm{T}$, such that concentrations at age 70 are approximately half of what is observed at ages 20-29 [28, 29]. Some behavioral sequelae associated with aging and decreased androgens include poorer performance in spatial tasks, greater anxiety and depression, and decreased sexual motivation [30-35]. In addition to androgen-sensitive changes in behavior, there are physiological changes, such as increased risk for BPH and prostate cancer [36]. These physiological changes worsen with aging, as frequency of moderate urinary symptoms related to BPH rise from $13 \%$ in the fifth to $28 \%$ in the eighth decade of life [37]. Thus, advanced aging is another example of effects of low androgen levels on many tissues of the body, including the brain, with reproductive and cognitive consequences.

Older male rodents demonstrate similar behavioral decline to that of aging men. Aged rodents display decreased sexual behavior and impaired cognitive performance in spatial tasks, and increased depression-like behavior [38-41]. Extirpation of the testes, a primary source of androgens, via gonadectomy (GDX) can reduce plasma levels of androgens similar to the low levels in advanced aging and can be considered a model of age-related androgen decline [40, 42]. Separate studies have shown that GDX of rodents produces behavioral effects similar to those seen with aging, including decreased sexual behavior and impaired cognitive performance and increased anxiety and depressive behavior [43-46]. Moreover, chronic mild unpredictable stress produces greater depression-like behavior of GDX rats coincident with decreased proliferation of new cells in the hippocampus, decreased neurogenesis, and lower expression of the protein polysialylated neural cell adhesion molecule, which is associated with neural plasticity [47].

Disruptions of Hormones Consequences of very low androgen levels are clear. Simply, when androgen concentrations are low, demasculinization is observed. For example, in humans, 
low fetal levels of DHT in individuals with a deficiency in the type II isoenzyme of $5 \mathrm{a}-\mathrm{R}$ produce birth defects in male external genitalia [48]. Also, it was noted that male pattern baldness (MPB) is rare in these individuals, which in the general population of men is prevalent (up to $70 \%$ of men will experience MPB at some point in their lives [49]). Importantly, the drug finasteride, which is used to treat MPB, blocks 5a-reduction of T to DHT. As such, changes to the androgen levels, as described herein, also result from exposure to finasteride. Clinical and adverse effects of this drug as reported [50] are consistent with the robust effects of changes in available androgens demonstrated in the literature with changes in androgen levels.

When we think about how steroids produce male- or female-typical phenotypes, there is masculinization along with defeminization in males, and demasculinization and feminization in females. Finasteride causes certain male individuals to show symptoms of demasculinization and feminization after exposure. Androgens produce masculinization and estradiol $\left(\mathrm{E}_{2}\right)$ and progestogens, like allopregnanolone (3a,5aTHP), produce feminization. There is a shunting of metabolism via $5 \mathrm{a}-\mathrm{R}$ with finasteride. This produces acute and persistent effects on other steroid pathways, such that $\mathrm{T}$ and $3 \mathrm{a}-$ diol are increased, but DHT is decreased [51, 52]. Furthermore, there are reductions in the pregnane neurosteroid, 3a,5a-THP, in which $5 \mathrm{a}-\mathrm{R}$ is a rate-limiting step in its production [51, 52]. Indeed, among Fischer 344 rats, levels of $\mathrm{T}$ and its $5 \mathrm{a}$-reduced, but not aromatized, metabolites decline with aging (coincident with age-related changes in brain function and the body [40]). Among aging men, $E_{2}$ levels remain unchanged or increase, resulting in a decrease in the ratio of $T$ to $E_{2}[29,53]$. A clear example of feminizing effects of finasteride is gynecomastia, enlargement of the breast tissues.

\section{Use of Finasteride to Study Androgens}

Finasteride alters the metabolism of $\mathrm{T}$ to its aromatase pathways vis-a-vis its inhibition of DHT synthesis; the end result here is an increased ratio of $\mathrm{E}_{2}$ to T/DHT producing gynecomastia [54] and changes in pregnane steroids. Gynecomastia is a robust and irreversible feminizing change in the body. The sum of these changes is that you can have feminizing and demasculinizing effects of finasteride among men (which look similar to aging, e.g., reduced musculature, changes in fat deposition, and increased breast development) and results in effects typically associated with aging (feminization and demasculinization).

There are also feminizing effects of finasteride for brain function. The clearest examples here relate to the robust psychological effects of finasteride use among men. That is, they report an increase in female-typical symptoms and disorders - anxiety and depression. Times of great changes in hormones among women are associated with increased incidence of anxiety and depression disorders, such as postpartum depression, premenstrual dysphoric disorder, and peri-menopausal depression $[55,56]$. In these disorders, it is not low levels per se that seem to predispose women to them, but the changes in circulating hormone levels [55-57]. Also, in the case of finasteride exposure and resulting anxiety and depression, there are impairments in neurosteroids; the role of neurosteroids specifically for mood and its disorders has been a topic of interest in many laboratories including our own [56]. Table 1 summarizes some of the symptoms of post-finasteride syndrome (PFS) that most clearly align with evidence of its demasculinizing and feminizing effects. Post-finasteride syndrome is a condition characterized by altered circulating and brain steroid levels and adverse physical and psychological effects that occur even after finasteride treatment is ceased $[50,54,58-62]$.

Clinical Use of Finasteride Finasteride is the first approved 5a$\mathrm{R}$ inhibitor for treatment of benign prostate hyperplasia (BPH) and MPB (aka androgenetic alopecia) [63]. Finasteride was first marketed by Merck as Proscar (for BPH) and Propecia (for MPB) in 1992 and 1997, respectively [64]. These clinical applications are based on the ability of finasteride to inhibit the $5 \mathrm{a}-\mathrm{R}$ enzyme with resulting reductions of T's metabolism to DHT. However, off-label uses can include reduction of side effects of anabolic androgenic steroid use or to promote demasculinization and feminization among transgender women [65]; some of these types of usages entered the public knowledge with the news of a joint effort between Florida and New York to clamp down on illegal steroid trafficking [66]. Just as off-label use of finasteride prevails, before it was approved for MPB, it was being used for this off-label, and produced profound effects on neurological function through inhibiting neurosteroidogenesis. Indeed, one of our patients with catamenial epilepsy nearly succumbed to intractable seizures when her uncle, a dermatologist, prescribed finasteride for off-label use [23]. Although it was first thought that $5 \alpha-\mathrm{R}$ (the enzyme that finasteride targets) was not expressed in the brain, more recent research has shown this is not true. $5 \alpha$ Reductase has expression in other tissues as well $[67,68]$. As such, the effects of the drug go beyond just the scalp for the male MPB effect.

Finasteride Beyond the Scalp and in the Brain Research from our lab has demonstrated that finasteride alters behavior of male rodents. Gonadectomized or gonadally intact rats were administered T-containing, or empty, silastic capsules in conjunction with a $5 \mathrm{a}-\mathrm{R}$ inhibitor or an aromatase inhibitor. All rats were tested for reproductive, social, cognitive, and affective behavior; prostate mass was determined; and androgens were measured in plasma and brain. Blocking T's metabolism 
Table 1 Finasteride significantly decreased prostate weight, increased latency to vote, time spent in overall social interaction, latencies to finding the hidden platform 2 in a water maze, number of entries to the light side, and the light/dark transition task

\begin{tabular}{|c|c|c|c|c|c|c|c|c|}
\hline & \multicolumn{8}{|c|}{ Gonad condition } \\
\hline & \multicolumn{4}{|c|}{ Gonadectomized } & \multicolumn{4}{|l|}{ Intact } \\
\hline & \multicolumn{8}{|c|}{ Androgen condition } \\
\hline & \multicolumn{2}{|c|}{ Vehicle } & \multicolumn{2}{|c|}{ Testosterone } & \multicolumn{2}{|l|}{ Vehicle } & \multicolumn{2}{|c|}{ Testosterone } \\
\hline & \multicolumn{8}{|c|}{ Inhibitor condition } \\
\hline & Veh & Fin & Veh & Fin & Veh & Fin & Veh & Fin \\
\hline Prostate weight (g) & 0.4 & 0.3 & 0.5 & 0.4 & 0.5 & 0.4 & 0.6 & 0.4 \\
\hline Latency to mate (s) & 550 & 600 & 500 & 600 & 300 & 350 & 250 & 300 \\
\hline Secs spent in social interaction & $35 \pm 6$ & $29 \pm 4$ & $25 \pm 3$ & $41 \pm 8$ & $41 \pm 10$ & $59 \pm 13$ & $37 \pm 3$ & $41 \pm 8$ \\
\hline (\% time with novel object) & 50 & 70 & 70 & 60 & 70 & 50 & 70 & 70 \\
\hline Latencies secs to finding platform in Morris Water maze & $61 \pm 4$ & $74 \pm 8$ & $61 \pm 7$ & $71 \pm 7$ & $62 \pm 6$ & $63 \pm 5$ & $59 \pm 7$ & $65 \pm 5$ \\
\hline No. of entries to light side in light/dark transition task & 1 & 1 & 2 & 1 & 4 & 3 & 3 & 2 \\
\hline
\end{tabular}

to its 5a-reduced metabolite, DHT, via systemic finasteride significantly decreased prostate weight and sexual behavior of male rats. In addition, in this study, there was a trend for finasteride to reduce cognitive performance in the water maze task (see Table 2). Importantly, the effects described here in this study show that manipulations of androgens with finasteride altered steroid levels and behavior well after finasteride from administration was cleared by the body. This study supports and extends previous work on androgen metabolism for trophic effects, as measured by prostate mass and behavioral effects in this study. For example, GDX of young male rats decreased prostate weight as has been demonstrated previously [64, 69]; herein, this phenomenon occurred concurrent with lower levels of DHT and T in plasma and brain, and unchanged or increased $E_{2}$ levels. This lower androgen to $E_{2}$ ratio that was observed here in male rats is similar to that observed among aged men. Concomitant with these changes in androgen levels, there were robust effects of GDX to decrease reproductive functions, including sexual responding and prostate weight. Others have reported that prostate weight $[64,69]$ and sexual behavior $[44,70,71]$ were reduced with GDX. Brain circuitry for this effect likely involves the hypothalamus and midbrain, which mediate reward, motivation, and sexual behavior of rodents [72, 73]. In our study, we observed reduced androgen formation in the midbrain and hypothalamus, areas related to sexual function, following GDX. Moreover, reductions in androgens following GDX were also observed in the hippocampus and cortex, regions that are considered to be critical for cognitive and anxiety-like behavior $[45,74,75]$, and sensitive to androgens for these functions [43, 76-83]. Together, these effects suggest a role of androgens for growth in body and neural plasticity, and that these effects can persist longer than the time for which the androgen manipulations occur.
Table 2 Overlapping symptoms of post-finasteride syndrome (PFS) and traumatic brain injury (TBI)

\begin{tabular}{ll}
\hline Demasculinization & Feminization \\
\hline Steroid levels & \\
$\square$ Androgens & $\&<$ Estrogens \\
Variable levels of progestins & Variable levels of pituitary/adrenal steroids \\
Physical effects & \\
$\square$ Testes size & $\&<$ Breast tissue \\
$\square$ Sexual motivation and/or performance & $\&<$ Need for affiliation, due to isolation \\
(PFS) absent (TBI) & \\
Cognitive behavior & $\&<$ Verbal \\
Spatial performance & \\
Social/emotional behavior & $\&<$ Depression, anxiety, erratic behavior, suicidality \\
\hline
\end{tabular}


Through competitive binding, finasteride is a potent inhibitor of type II 5a-R (mean inhibitory concentration, or IC50, of $69 \mathrm{nM}$ ). Finasteride has also been shown to be similarly potent in binding to the type III isoenzyme of 5a-R (IC50 17.4 vs. $14.3 \mathrm{nM}$ for $5 \mathrm{a}-\mathrm{R}$ type II) when tested in a HEK-293 in vitro cell preparation [84]. The type II isoenzyme of 5a-R predominates in the clinical targets for MPB and BPH, the hair follicles and prostate, respectively, and is also expressed in the liver, seminal vesicle, and epididymis $[67,85]$. Approximately onethird of circulating levels of DHT are due to the actions of the type I isoenzymes, with the rest from the actions of the other isoenzymes $[67,85,86]$. Based on preferential binding and the tissue-specific expression of 5a-R type II, finasteride was initially considered to have little potential for adverse actions in other tissues, beyond the hair follicles and prostate. Importantly, there are differential expression patterns of 5a-R isoenzymes in different tissues, and developmental periods $[67,68]$. Finasteride binds both types II and III, which are expressed in the brain opening the door to these other neural effects.

We will focus here on these expression pattern differences in human tissues and developmental periods to explain the clinical usage of finasteride. For example, in adult humans, 5a-R type III is ubiquitously expressed, but types I and II show different patterns of expression in the brain, genital and nongenital skin, prostate, internal and external male genitalia, liver, kidneys, and pancreas [68, 85, 87-91]. Human type I isoenzyme of $5 \mathrm{a}-\mathrm{R}$ is found mainly in high levels in sebaceous glands of the scalp and the majority of skin tissue as well as the brain, liver, and muscles $[85,92]$ and low levels in the prostate (NB: levels may increase in prostate cancer cells [93]). Like types I and III, human type II isoenzyme of 5a-R is primarily expressed in the hair follicles, epididymis, and prostate [85], and can be expressed in various structures of the brain (but the data on this are more limited than for these other well-characterized tissues) $[68,88,94]$.

A recent study, however, in rats demonstrates regional patterns of 5a-R type II expression [95]. Specifically, 5a-R type II was expressed in the olfactory bulb, cortical regions including olfactory bulb, corticolimbic regions (prefrontal and somatosensory cortex, hippocampus, amygdala), thalamus, and cerebellum [95]. This expression pattern seemed to be limited to neurons; moreover, there was 5a-R type II expression in GABA cells in the striatum, hippocampus, and cortex [95]. Given that these isoenzymes have distinct expression patterns, they represent distinct therapeutic targets as well as adverse side effects from their exposure to finasteride $[86,96]$.

The role of 5a-R for brain function is also supported by looking at studies in mice that are genetic knockouts. $5 \mathrm{a}-$ $\mathrm{R}$ knockout mice are a valuable research tool in which the expression of the type I $5 a-R$ gene is perturbed. This results in deficiencies in its protein product, the $5 \mathrm{a}-\mathrm{R}$ enzyme throughout life [97, 98]. Effects of reducing this enzyme can be robust. For example, female mice that are deficient in $5 \mathrm{a}-\mathrm{R}$ have smaller litter sizes (2-3 pups compared to 8 in wild-type controls); this greater rate of fetal death is due to higher $\mathrm{E}_{2}$ concentrations producing toxicity because of failure to metabolize androgens via the $5 \mathrm{a}$ $\mathrm{R}$ pathway [98]. In adults, we have observed additional evidence of brain trauma with knockout of this enzyme $[11,16]$ as well as increased anxiety [99-101] and aggression [12], poorer spatial cognition [102], and reduced sexual responding [103]. These mice also show different patterns of alcohol consumption [104], similar to what is observed with finasteride administration to mice [105]. In addition to the behavioral and phenotypic effects of $5 a-R$ type II deficiency already discussed, there is further evidence of the role of $5 a-R$ for brain function and behavior of people. One such example has been reported recently [106]. In this pilot study, depressed patients and those that were not diagnosed with a psychiatric disorder were compared for 5a-R type I messenger RNA expression in the brain. Results showed that individuals with depression showed a more than $50 \%$ reduction in $5 \mathrm{a}-\mathrm{R}$ messenger RNA in prefrontal cortex Brodmann's area 9 (but not in the cerebellum [106]). In a follow-up experiment, levels of neurosteroids in this same region of the brain were reduced in depressed non-treated patients; depressed patients treated with antidepressants had increased neurosteroid levels [106]. These data show that altering $5 \mathrm{a}-\mathrm{R}$ gene expression can have robust effects on brain function and point to differences in steroid levels.

Finasteride's Effect on Neurosteroid Production A recent paper has investigated the effects of $5 \mathrm{mg}$ of finasteride (Proscar) that is used for BPH on neurosteroid levels [107]. In this report, older men (57-79 years old) were administered placebo or finasteride for 12 months and plasma levels of androstenedione, T, DHT, DHT sulfate, 3a-diol glucuronide, and androsterone glucuronide were measured in serum by radioimmunoassay. As expected, there were no differences in the placebo control group; however, there were reductions in many of the steroids assessed even 1 month after finasteride treatment was initiated that generally persisted. For example, DHT, DHT sulfate, and 3a-diol glucuronide decreased by more than $70 \%$ among the users of finasteride in the first month of treatment compared to baseline levels; this occurred concomitantly with higher levels of $\mathrm{T}$ and androstenedione approximately $18 \%$ and $35 \%$, respectively. These data show altering steroid metabolism with finasteride can have actions beyond those at $5 \mathrm{a}-\mathrm{R}$ alone.

We know that neurosteroids play a significant role for protection of the brain following insult, cognition, and anxiety and depression [108-111]. Synthesis of neurosteroids requires $5 a-R$. As such, finasteride alters neurosteroid levels and can have robust effects clearly related to the adverse effects of finasteride that have been reported in men in the short term 
and long term following cessation of its use. For example, dysregulation of neurosteroid synthesis and androgen deficiency is associated with mood disorders, such as depression $[54,112]$. Of clinical relevance is consideration of long-term effects of androgen manipulations that extend beyond the treatment period.

\section{Neuroendocrine Effects of Prefrontal Synthesis}

In cases of PFS, there appear to be long-term consequences of changing androgen milieu that may be independent of specific levels of androgen concentrations at a particular time. For example, reports indicate long-term changes in these behaviors as well as neuroactive steroid levels of men [51, 52, 54]. In the report by Melcangi and colleagues [52], three men who had taken finasteride for MPB and reported physical and psychological symptoms at assessment, which persisted after cessation of finasteride (e.g., stiffness, cramps, and tremors in muscles, chronic fatigue, and symptoms of anxiety and depression), had neurosteroid levels measured in cerebrospinal fluid (CSF) and plasma. Levels of these steroids in tissues were compared in these three patients to five control subjects who were around the same age, but had not taken finasteride. Levels of neurosteroids in CSF and plasma were measured with liquid chromatography-tandem mass spectrometry (LC/MS). In addition to some differences between finasteride patients, there were greater effects for some steroids when assessing across the finasteride treatment group and the control group. Among the finasteride group, compared to the control group, there were lower levels of several neurosteroids in CSF: 3a,5a-THP, isopregnanolone, and DHT; there were also higher levels of $\mathrm{T}_{\text {and }} \mathrm{E}_{2}$ in CSF. There were lower plasma levels of dihydroprogesterone, but higher levels of 3a-diol and $\mathrm{E}_{2}$, of former, symptomatic users of finasteride compared to healthy controls.

A follow-up study from this group [51] demonstrated a similar pattern. In this study, former users of finasteride $(n=$ 7) that were showing physical and psychological adverse effects much like the previously described Melcangi and colleagues study were compared to age-matched, healthy men (control group, $n=12$ ). In this study, LC/MS was used to measure levels of several steroids in CSF and plasma: T, DHT, 3a-diol, 3 $\beta$-diol, $\mathrm{E}_{2}$, pregnenolone, progesterone, dihydroprogesterone, 3a,5a-THP, isopregnanolone, and dehydroepiandrosterone (DHEA).

Results showed that former users of finasteride had higher levels of pregnenolone in CSF and plasma compared to controls and no differences in DHEA. Progesterone was reduced in CSF, but not altered in plasma, of former finasteride users compared to controls. Progesterone's metabolites (dihydroprogesterone, $3 a, 5 a-T H P$, isopregnanolone) were reduced in CSF and plasma of former finasteride users. Testosterone and 3a-diol were increased in CSF and plasma among former finasteride users with concomitant reduction in CSF levels of DHT (with no change in plasma levels of DHT). The other androstane neurosteroids, $3 \beta$ diol and $E_{2}$, were not detected or not changed in CSF, respectively, or were increased in plasma of former finasteride users compared to controls. Overall, this complex pattern of change in these neurosteroids shows that finasteride can have enduring effects on many different neurosteroids, even after it is no longer being used as treatment. That some steroids were increased and others decreased supports a general dysregulation of these steroids as measured in CSF and plasma. These steroid levels were not assessed in isolation among these former users of finasteride. Indeed, there were persistent physical and psychological effects among these men, coincident with this dysregulation in neuroendocrine function.

In sum, finasteride acting at $5 \mathrm{a}-\mathrm{R}$ interferes with many downstream or alternative pathways for production of steroids; reducing one pathway increases activity of other enzymes to increase or decrease neurosteroids that have many effects. Perhaps most importantly, these actions of finasteride via $5 \mathrm{a}-\mathrm{R}$ are not limited to current treatment, but can have lasting effects on patients long after they have discontinued finasteride.

\section{Neurosteroids and Receptor Targets}

Decades of work by many laboratories show that neuro(active)steroids have rapid effects, including those on neuronal excitability and synaptic function [113-121]. These rapid effects are understood to involve direct or indirect modulation of ion-gated or other metabotropic neurotransmitter receptors, rather than traditional actions via cognate nuclear steroid hormone receptors; these actions are referred to as novel or non-traditional actions of steroids. Indeed, these findings about neurosteroids have changed many of these aforementioned concepts regarding the possible sources, mechanisms, and effects of steroids. In brief, unlike circulating hormones, neurosteroids are produced in the brain and can have actions locally at neurotransmitter receptors. This means that they can change the function of neuronal circuity locally and rapidly. Our research and other research published in the scientific community demonstrate many receptor targets for neurosteroids, including GABA, dopamine, and sigma receptors. As such, finasteride exposure that results in changes to neurosteroid levels also effects GABA, dopamine, sigma, and ER $\beta$ receptors, as well as a number of other substrates which are beyond the scope of this report. We propose further that these (de)masculinization and (de)feminization steroid pathways can be re-organized in adult males, such as naturally occurs with aging or purposely with finasteride administration or when certain insults occur to the brain as with mild traumatic brain injury (mTBI). In males, steroid hormones have robust effects on many tissues even in very low concentrations. Testosterone is the most abundant androgen in circulation. It is produced by testicular Leydig cells following 
sequential signaling by gonadotropin-releasing hormone $(\mathrm{GnRH})$ from the hypothalamus and luteinizing hormone from the anterior pituitary; yet, only $3 \%$ is free with the other $97 \%$ being bound to proteins, such as albumen and sexhormone binding globulin. Testosterone that is bound is not able to diffuse across cell membrane to have actions at its primary target, ARs. Despite a small percentage of T being free in circulation, those physiological levels have actions at many tissue targets with clear functions. During early fetal development, $\mathrm{T}$ is important for promoting Wolffian duct development into the internal male genitalia, as well as other organizing effects on the brain. Many of the effects of T occur following its metabolism to DHT via $5 \mathrm{a}-\mathrm{R}$ within target cells, such as those of the hair follicles, prostate, and brain. Likewise, DHT has important effects during fetal development to promote differentiation and growth of the male external genitalia and the prostate gland. Our research and other's research have shown that natural changes in steroids or induced changes can have a profound effect on behavior and phenotype and that part of this mechanism involves changes in neurosteroids $[122 \bullet, 123 \bullet, 124 \bullet \bullet, 125,126,127 \bullet \bullet]$.

\section{Compliance with Ethical Standards}

Conflict of Interest The authors declare that they have no conflicts of interest.

Human and Animal Rights and Informed Consent This article does not contain any studies with human or animal subjects performed by any of the authors.

Open Access This article is licensed under a Creative Commons Attribution 4.0 International License, which permits use, sharing, adaptation, distribution and reproduction in any medium or format, as long as you give appropriate credit to the original author(s) and the source, provide a link to the Creative Commons licence, and indicate if changes were made. The images or other third party material in this article are included in the article's Creative Commons licence, unless indicated otherwise in a credit line to the material. If material is not included in the article's Creative Commons licence and your intended use is not permitted by statutory regulation or exceeds the permitted use, you will need to obtain permission directly from the copyright holder. To view a copy of this licence, visit http://creativecommons.org/licenses/by/4.0/.

\section{References}

Papers of particular interest, published recently, have been highlighted as:

- Of importance

•. Of major importance

1. Baulieu EE. Steroid hormone receptors. Expos Annu Biochim Med. 1980;34:1-25.

2. Mellon S. H. Neurosteroid regulation of central nervous system development. Pharmacol Ther. Oct;116(1):107-124. (2007).
3. Kellogg CK, Frye CA. Endogenous levels of 5 alpha-reduced progestins and androgens in fetal vs. adult rat brains. Brain Res Dev Brain Res. 115(1):17-24.

4. Kitay J. I. (1963). Effects of estradiol on pituitary-adrenal function in male and female rats. (1999).Endocrinology. Jun;72:947-954.

5. Beato M. Gene regulation by steroid hormones. Cell. 1989;56(3): 335-44.

6. Reddy DS, Jian K. The testosterone-derived neurosteroid androstanediol is a positive allosteric modulator of GABAA receptors. J Pharmacol Exp Ther. 2010;334(3):1031-41. https:// doi.org/10.1124/jpet.110.169854.

7. Clark AS, Costine BA, Jones BL, Kelton-Rehkopf MC, Meerts SH, Nutbrown- Greene LL, et al. Sex- and age-specific effects of anabolic androgenic steroids on reproductive behaviors and on GABAergic transmission in neuroendocrine control regions. Brain Research. 2006;1126(1):122-38. https://doi.org/10.1016/j. brainres.2006.08.081.

8. Pak TR, Chung WC, Lund TD, Hinds LR, Clay CM, Handa RJ. The androgen metabolite, 5alpha-androstane-3beta, 17beta-diol, is a potent modulator of estrogen receptor- beta1-mediated gene transcription in neuronal cells. Endocrinology. 2005;146(1): 14755. https://doi.org/10.1210/en.2004-0871.

9. Edinger KL, Frye CA. Androgens' effects to enhance learning may be mediated in part through actions at estrogen receptor- $\beta$ in the hippocampus. Neurobiology of Learning and Memory. 2007;87:78-85. https://doi.org/10.1016/j.nlm.2006.07.001.

10. Frye CA, Duncan JE, Basham M, Erskine MS. Behavioral effects of 3 alpha- androstanediol. II: Hypothalamic and preoptic area actions via a GABAergic mechanism. Behav Brain Res. 1996;79(1-2):119-30.

11. Frye C. A., Rhodes M. E., Walf A., Harney J. Progesterone reduces pentylenetetrazol-induced ictal activity of wild-type mice but not those deficient in type I 5alpha-reductase. Epilepsia. 2002;43 Suppl 5:14-17.

12. Frye CA, Rhodes ME, Walf A, Harney JP. Testosterone enhances aggression of wild-type mice but not those deficient in type I 5alpha-reductase. Brain Res. 2002;948(1-2):165-70. https://doi. org/10.1016/s0006-8993(02)03076-7.

13. Solomon ZJ, Mirabal JR, Mazur DJ, Kohn TP, Lipshultz LI, Pastuszak AW. Selective androgen receptor modulators: current knowledge and clinical applications. Sex Med Rev. 2019;7(1):84 94. https://doi.org/10.1016/j.sxmr.2018.09.00.

14. Frau R, Mosher LJ, Bini V, Pillolla G, Pes R, Saba P, et al. The neurosteroidogenic enzyme $5 \alpha$-reductase modulates the role of D1 dopamine receptors in rat sensorimotor gating. Psychoneuroendocrinology. 2016;63:59-67. https://doi.org/10. 1016/j.psyneuen.2015.09.014. This publication shows that finasteride's effects on pre-pulse inhibition require actions through D1- but not D2-like receptors.

15. Frye CA, Rhodes ME, Rosellini R, Svare B. The nucleus accumbens as a site of action for rewarding properties of testosterone and its 5alpha-reduced metabolites. Pharmacol Biochem Behav. 2002;74(1):119-27.

16. Frye CA, Park D, Tanaka M, Rosellini R, Svare B. The testosterone metabolite and neurosteroid 3alpha-androstanediol may mediate the effects of testosterone on conditioned place preference. Psychoneuroendocrinology. 2001;26(7):731-50.

17. Rosellini RA, Svare BB, Rhodes ME, Frye CA. The testosterone metabolite and neurosteroid 3alpha-androstanediol may mediate the effects of testosterone on conditioned place preference. Brain Res Brain Res Rev. 2001;37(1-3):162-71.

18. Misiak B, Frydecka D, Loska O, Moustafa AA, Samochowiec J, Kasznia J, et al. Testosterone, DHEA and DHEA-S in patients with schizophrenia: a systematic review and meta-analysis. Psychoneuroendocrinology. 2018;89:92-102. https://doi.org/10. 1016/j.psyneuen.2018.01.007Review. 
19. Smith CD, Wekstein DR, Markesbery WR, Frye CA. 3alpha, 5alpha-THP: a potential plasma neurosteroid biomarker in Alzheimer's disease perhaps non-Alzheimer's dementia. Psychopharmacology (Beryl). 2006;186(3):481-5.

20. Herzog AG, Drislane FW, Schomer DL, Pennell PB, Bromfield EB, Kelly KM, et al. Differential effects of antiepileptic drugs on sexual function and reproductive hormones in men with epilepsy: interim analysis of a comparison between lamotrigine and enzyme-inducing antiepileptic drugs. Epilepsia. 2004;45(7):7648. https://doi.org/10.1111/j.0013-9580.2004.60703.x.

21. Herzog AG, Drislane FW, Schomer DL, Pennell PB, Bromfield EB, Dworetzky BA, et al. Differential effects of antiepileptic drugs on sexual function and hormones in men with epilepsy. Neurology. 2005;(7):65, 1016-1020. https://doi.org/10.1212/01. wnl.0000178988.78039.40.

22. Herzog AG, Drislane FW, Schomer DL, Pennell PB, Bromfield EB, Dworetzky BA, et al. Differential effects of antiepileptic drugs on neuroactive steroids in men with epilepsy. Epilepsia. 2006;47(11):1945-8. https://doi.org/10.1111/j.1528-1167.2006. 00826.x.

23. Herzog AG, Frye CA. Seizure exacerbation associated with inhibition of progesterone metabolism. Ann Neurol. 2003;53(3):390 1. https://doi.org/10.1002/ana.10508.

24. Herzog AG, Frye CA. Allopregnanolone levels and seizure frequency in progesterone-treated women with epilepsy. Neurology. 2014;83(4):345-8. https://doi.org/10.1212/WNL. 0000000000000623 .

25. Phoenix CH, Goy RW, Gerall AA, Young WC. Organizing action of prenatally administered testosterone propionate on the tissues mediating mating behavior in the female guinea pig. Endocrinology. 1959;65:369-82.

26. Hiort O. Androgens and puberty. Best Pract Res Clin Endocrinol Metab. 2002;16(1):31-41. https://doi.org/10.1053/beem.2002. 0178.

27. Morley JE, Kaiser FE, Perry HM III, Patrick P, Morley PM, Stauber PM, et al. Longitudinal changes in testosterone, luteinizing hormone, and follicle-stimulating hormone in healthy older men. Metabolism. 1997;46(4):410-3.

28. Schatzl G, Madersbacher S, Temml C, Krenn-Schinkel K, Nader A, Sregi G, et al. Serum androgen levels in men: Impact of health status and age. Urology. 2003;61(3):629-33.

29. Vermeulen A. Andropause. h. 2000;34(1):5-15.

30. Davidson JM, Kwan M, Greenleaf WJ. Hormonal replacement and sexuality in men. Clin Endocrinol Metab. 1982;11(3):599623

31. Basaria S, Dobs AS. Hypogonadism and androgen replacement therapy in elderly men. Am J Med. 2001;110(7):563-7.

32. Basaria S, Lieb J 2nd, Tang AM, DeWeese T, Carducci M, Eisenberger $\mathrm{M}$, et al. Long-term effects of androgen deprivation therapy in prostate cancer patients. Clin Endocrinol (Oxf). 2002;56:779-86.

33. Morley JE. Androgens and aging. Maturitas. 2001;38:61-73.

34. Janowsky JS, Oviatt SK, Orwoll ES. Testosterone influences spatial cognition in older men. Behav Neurosci. 1994;108(2):325-32.

35. Seidman SN, Araujo AB, Roose SP, Devanand DP, Xie S, Cooper $\mathrm{TB}$, et al. Low testosterone levels in elderly men with dysthymic disorder. Am J Psychiatry. 2002;159(3):456-9.

36. Untergasser G, Rumpold H, Hermann M, Dirnhofer S, Jilg G, Berger P. Proliferative disorders of the aging human prostate: involvement of protein hormones and their receptors. Exp Gerontol. 1999;34(2):275-87.

37. Kaplan SA. Benign prostatic hyperplasia: patient perceptions and financial reality regarding the aging American prostate. $J$ Urol. 2005; $173: 1852$

38. Barnes CA. Aging and the physiology of spatial memory. Neurobiol Aging. 1988;9:563-8.
39. Chambers KC, Thornton JE, Roselli CE. Age-related deficits in brain androgen binding and metabolism, testosterone, and sexual behavior of male rats. Neurobiol Aging. 1991;12(2):123-30.

40. Frye CA, Paris JJ. Effects of neurosteroid actions at N-methyl-daspartate and GABAA receptors in the midbrain ventral tegmental area for anxiety-like and mating behavior of female rats. Psychopharmacology. 2010;213(1):93-103.

41. Spruijt BM, Meyerson BJ, Höglund U. Aging and sociosexual behavior in the male rat. Behav Brain Res. 1989;32(1):51-61.

42. Krey LC, McGinnis MY. Time-courses of the appearance/ disappearance of nuclear androgen + receptor complexes in the brain and adenohypophysis following testosterone administration/ withdrawal to castrated male rats: relationships with gonadotropin secretion. J Steroid Biochem. 1990;35(3-4):403-8.

43. Adler A, Vescovo P, Robinson J, Kritzer M. Gonadectomy in adult life increases tyrosine hydroxylase immunoreactivity in the prefrontal cortex and decreases open field activity in male rats. Neuroscience. 1999;89:939-54. https://doi.org/10.1016/s03064522(98)00341-8.

44. Hull EM, Dominguez JM. Sexual behavior in male rodents. Horm Behav. 2007;52(1):45-55. https://doi.org/10.1016/j.yhbeh.2007. 03.030.

45. Aubele T, Kaufman R, Montalmant F, Kritzer MF. Effects of gonadectomy and hormone replacement on a spontaneous novel object recognition task in adult male rats. Horm Behav. 2008;54: 44-252. https://doi.org/10.1016/j.yhbeh.2008.04.002.

46. Bernardi M, Genedani S, Tagliavini S, Bertolini A. Effect of castration and testosterone in experimental models of depression in mice behavioral. Neuroscience. 1989;103:1148-50.

47. Wainwright SR, Lieblich SE, Galea LA. Hypogonadism predisposes males to the development of behavioural and neuroplastic depressive phenotypes. Psychoneuroendocrinology. 2011;35: 1327-41.

48. Imperato-McGinley J, Miller M, Wilson JD, Peterson RE, Shackleton C, Gajdusek DC. A cluster of male pseudohermaphrodites with 5 alpha-reductase deficiency in Papua New Guinea. Clin Endocrinol (Oxf). 1991;34(4):293-8.

49. McElwee KJ, Shapiro JS. Promising therapies for treating and/or preventing androgenic alopecia. Skin Therapy Lett. 2012;17(6):14.

50. Irwig MS. Persistent sexual side effects of finasteride: could they be permanent? J Sex Med. 2012;9(11):2927-32. https://doi.org/ 10.1111/j.1743-6109.2012.0286.x.

51. Caruso D, Melis M, Fenu G, Giatti S, Romano S, Grimoldi M, et al. Neuroactive steroid levels in plasma and cerebrospinal fluid of male multiple sclerosis patients. Journal of Neurochemistry. 2014;130(4):591-7. https://doi.org/10.1111/jnc.12745.

52. Melcangi RC, Caruso D, Abbiati F, Giatti S, Calabrese D, Piazza F, et al. Neuroactive steroid levels are modified in cerebrospinal fluid and plasma of post-finasteride patients showing persistent sexual side effects and anxious/depressive symptomatology. $J$ Sex Med. 2013;10(10):2598-603. https://doi.org/10.1111/jsm. 12269.

53. Ellem SJ, Risbridger GP. The dual, opposing roles of estrogen in the prostate. Annals of the New York Academy of Sciences. 2009;1155:174-86. https://doi.org/10.1111/j.1749-6632.2009. 04360.x.

54. Traish AM, Hassani J, Guay AT, Zitzmann M, Hansen ML. Adverse side effects of $5 \alpha$-reductase inhibitors therapy: persistent diminished libido and erectile dysfunction and depression in a subset of patients. J Sex Med. 2011;8(3):872-8.

55. Walf AA, Frye CA. A review and update of mechanisms of estrogen in the hippocampus and amygdala for anxiety and depression behavior. Neuropsychopharmacology. 2006;31(6):1097-111.

56. Frye CA. Neurosteroids' effects and mechanisms for social, cognitive, emotional, and physical functions. Psychoneuroendocrinology. 
2009;34(Suppl 1):S143-61. https://doi.org/10.1016/j.psyneuen.2009. 07.005 .

57. Schiller CE, Johnson SL, Abate AC, Schmidt PJ, Rubinow DR. Reproductive steroid regulation of mood and behavior. Compr Physiol. 2016;6(3):1135-60. https://doi.org/10.1002/cphy. c150014.

58. Ganzer CA, Jacobs AR, Iqbal F. Persistent sexual, emotional, and cognitive impairment post-finasteride: a survey of men reporting symptoms. Am J Mens Health. 2015;9(3):222-8. https://doi.org/ $10.1177 / 1557988314538445$.

59. Irwig MS. Depressive symptoms and suicidal thoughts among former users of finasteride with persistent sexual side effects. $J$ Clin Psychiatry. 2012;73(9):1220-3. https://doi.org/10.4088/ JCP.12m07887.

60. Irwig MS. Androgen levels and semen parameters among former users of finasteride with persistent sexual adverse effects. JAMA Dermatol. 2014;150(12):1361-3. https://doi.org/10.1001/ jamadermatol.2014.1830.

61. Irwig MS, Kolukula S. Persistent sexual side effects of finasteride for male pattern hair loss. J Sex Med. 2011;8(6):1747-53. https:// doi.org/10.1111/j.1743-6109.2011.02255.x.

62. Traish AM, Haider KS, Doros G, Haider A. Finasteride, not tamsulosin, increases severity of erectile dysfunction and decreases testosterone levels in men with benign prostatic hyperplasia. Horm Mol Biol Clin Investig. 2015;23(3):85-96.

63. Rittmaster RS. Finasteride. N Engl J Med. 1994;330:120-5.

64. Brooks JR, Primka RL, Berman C, Krupa DA, Reynolds GF, Rasmusson GH. Topical anti-androgenicity of a new 4azasteroid in the hamster. Steroids. 1991;56(8):428-33.

65. Spack NP. Management of transgenderism. JAMA. 2013;309(5): 478-84. https://doi.org/10.1001/jama.2012.165234.

66. Signature Pharmacy Inc., et al., v. P. David Soares, et al., Case 6: 08-cv-01853-GAP- GJK (M.D. Fla. June 30, 2010). (2010).

67. Finn DA, Beadles-Bohling AS, Beckley EH, Ford MM, Gililland $\mathrm{KR}$, Gorin-Meyer RE, et al. A new look at the 5alpha-reductase inhibitor finasteride. CNS Drug Rev. 2006;12(1):53-76. https:// doi.org/10.1111/j.1527-3458.2006.00053.x.

68. Azzouni F, Godoy A, Li Y, Mohler J. The 5-Alpha-Reductase isozyme family: a review of basic biology and their role in human diseases. Advances in Urology. 2012:1-18. https://doi.org/10. 1155/2012/530121.

69. Borst SE, Conover CF, Carter CS, Gregory CM, Marzetti E, Leeuwenburgh $\mathrm{C}$, et al. Anabolic effects of testosterone are preserved during inhibition of $5 \alpha$-reductase. Am J Physiol Endocrinol Metab. 2007;293:507-14. https://doi.org/10.1152/ ajpendo.00130.2007.

70. Davidson JM. Characteristics of sex behaviour in male rats following castration. Anim Behav. 1966;14(2):266-72.

71. McGinnis MY, Mirth MC, Zebrowski AF, Dreifuss RM. Critical exposure time for androgen activation of male sexual behavior in rats. Physiol Behav. 1989;46:159-65.

72. Brackett NL, Edwards DA. Medial preoptic connections with the midbrain tegmentum are essential for male sexual behavior. Physiol Behav. 1984;32(1):79-84.

73. Murphy AZ, Rizvi TA, Ennis M, Shipley MT. The organization of preoptic- medullary circuits in the male rat: evidence for interconnectivity of neural structures involved in reproductive behavior, antinociception and cardiovascular regulation. Neuroscience. 1999;91:1103-16.

74. Sandstrom NJ, Kim JH, Wasserman MA. Testosterone modulates performance on a spatial working memory task in male rats. Horm Behav. 2006;50:18-26.

75. Kritzer MF, McLaughlin PJ, Smirlis T, Robinson JK. Gonadectomy impairs T-maze acquisition in adult male rats. Horm Behav. 2001;39:167-74.
76. Kaut KP, Bunsey MD. The effects of lesions to the rat hippocampus or rhinal cortex on olfactory and spatial memory: retrograde and anterograde findings. Cogn Affect Behav Neurosci. 2001;1(3): 270-86.

77. Brown MW, Wilson FAW, Riches IP. Neuronal evidence that inferomedial temporal cortex is more important than hippocampus in certain processes underlying recognition memory. Brain Res. 1987;409(1):158-62. https://doi.org/10.1016/00068993(87(90753-0.

78. Bitran D, Kellogg CK, Hilvers RJ. Treatment with an anabolicandrogenic steroid affects anxiety-related behavior and alters the sensitivity of cortical GABA(A) receptors in the rat. Horm Behav. 1993;27:568-83.

79. Frye CA, Seliga AM. Testosterone increases analgesia, anxiolysis, and cognitive performance of male rats. Cogn Affect Behav Neurosci. 2001;1(4):371-81.

80. Fernández-Guasti A, Martínez-Mota L. Orchidectomy sensitizes male rats to the action of diazepam on burying behavior latency: role of testosterone. Pharmacology Biochemistry and Behavior. 2003;75(2):473-9. https://doi.org/10.1016/s0091-3057(03) 00142-4.

81. Edinger KL, Frye CA. Testosterones analgesic, anxiolytic, and cognitive-enhancing effects may be due in part to actions of its $5 \alpha$-reduced metabolites in the hippocampus. Behavioral Neuroscience. 2004;118:1352-64. https://doi.org/10.1037/07357044.118.6.1352.

82. Frye CA, Edinger K, Sumida K. Androgen administration to aged male mice increases anti-anxiety behavior and enhances cognitive performance. Neuropsychopharmacology. 2008;33(5):1049-61. https://doi.org/10.1038/sj.npp.1301498.

83. Frye CA. Some rewarding effects of androgens may be mediated by actions of its 5alpha-reduced metabolite 3alpha-androstanediol. Pharmacol Biochem Behav. 2007;86(2):354-67. https://doi.org/ 10.1016/j.pbb.2006.10.003.

84. Yamana K, Labrie F, Luu-The V. Human type $35 \alpha$-reductase is expressed in peripheral tissues at higher levels than types 1 and 2 and its activity is potently inhibited finasteride and dutasteride. Hormone Molecular Biology and Clinical Investigation. 2010;2(3):293-9.

85. Thigpen AE, Silver RI, Guileyardo JM, Casey ML, McConnell JD, Russell DW. Tissue distribution and ontogeny of steroid 5 alpha-reductase isozyme expression. J Clin Invest. 1993;92(2): 903-10.

86. Gisleskog PO, Hermann D, Hammarlund-Udenaes M, Karlsson MO. A model for the turnover of dihydrotestosterone in the presence of the irreversible 5 alpha-reductase inhibitors GI198745 and finasteride. Clin Pharmacol Ther. 1998;64(6):636-47. https://doi. org/10.1016/S0009-9236(98)90054-6.

87. Aumüller G, Eicheler W, Renneberg H, Adermann K, Vilja P, Forssmann WG. Immunocytochemical evidence for differential subcellular localization of $5 \alpha$-reductase isoenzymes in human tissues. Acta Anatomica. 1997;156(4):241-52.

88. Eicheler W, Dreher M, Hoffmann R, Happle R, Aumuller G. Immunohistochemical evidence for differential distribution of $5 \alpha$-reductase isoenzymes in human skin. British Journal of Dermatology. 1995;133:371-6. https://doi.org/10.1111/j.13652133.1995.tb02663.x.

89. Eicheler W, Seitz J, Steinhoff M, Forssmann WG, Adermann K, Aümuller G. Distribution of rat hepatic steroid $5 \alpha$-reductase 1 as shown by immunohistochemistry. Experimental and Clinical Endocrinology \& Diabetes. 1995;103:105-12. https://doi.org/10. 1055/s-0029-1,211,337.

90. Lunacek A, Schwentner C, Oswald J, Fritsch H, Sergi C, Thomas LN, et al. Fetal distribution of 5alpha-reductase 1 and 5alphareductase 2 , and their input on human prostate development. $J$ Urol. 2007;178(2):716-21. 
91. Godoy A, Kawinski E, Li Y, Oka D, Alexiev B, Azzouni F, et al. $5 \alpha$-reductase type 3 expression in human benign and malignant tissues: a comparative analysis during prostate cancer progression. Prostate. 2011;71(10):1033-46. https://doi.org/10.1002/pros. 21318.

92. Ellis JA, Panagiotopoulos S, Akdeniz A, Jerums G, Harrap SB. Androgenic correlates of genetic variation in the gene encoding $5 \alpha$-reductase type 1. Journal of Human Genetics. 2005;50:534-7. https://doi.org/10.1007/s10038-005-0289-x.

93. Titus MA, Schell MJ, Lih FB, Tomer KB, Mohler JL. Testosterone and dihydrotestosterone tissue levels in recurrent prostate cancer. Clin Cancer Res. 2005;11(13):4653-7.

94. Aumuller G, Eicheler W, Renneberg H, Adermann K, Vilja P, Forssmann WG. Immunocytochemical evidence for differential subcellular localization of 5-alphareductase isoenzymes in human tissues. Acta Anatomica (Basel). 1996;156:241-52.

95. Castelli MP, Casti A, Casu A, Frau R, Bortolato M, Spiga S, et al. Regional distribution of $5 \alpha$-reductase type 2 in the adult rat brain: an immunohistochemical analysis. Psychoneuroendocrinology. 2013;38(2):281-93. https://doi.org/10.1016/j.psyneuen.2012.06. 008 .

96. Caruso D, Abbiati F, Giatti S, Romano S, Fusco L, Cavaletti G, et al. Patients treated for male pattern hair with finasteride show, after discontinuation of the drug, altered levels of neuroactive steroids in cerebrospinal fluid and plasma. The Journal of Steroid Biochemistry and Molecular Biology. 2015;146:74-9. https://doi.org/10.1016/j.jsbmb.2014.03.012.

97. Mahendroo MS, Cala KM, Russell DW. 5 alpha-reduced androgens play a key role in murine parturition. Mol Endocrinol. 1996;10(4):380-92.

98. Mahendroo MS, Cala KM, Landrum DP, Russell DW. Fetal death in mice lacking 5alpha-reductase type 1 caused by estrogen excess. Mol Endocrinol. 1997;11(7):917-27.

99. Frye CA, Edinger KL, Seliga AM, Wawrzycki JM. $5 \alpha$-reduced androgens may have actions in the hippocampus to enhance cognitive performance of male rats. Psychoneuroendocrinology. 2004;29:1019-27. https://doi.org/10.1016/j.psyneuen.2003.10. 004 .

100. Koonce CJ, Walf AA, Frye CA. Type $15 \alpha$-reductase may be required for estrous cycle changes in affective behaviors of female mice. Behavioural Brain Research. 2012;226(2):376-80. https:// doi.org/10.1016/j.bbr.2011.09.028.

101. Koonce CJ, Frye CA. Progesterone facilitates exploration, affective and social behaviors among wildtype, but not $5 \alpha$-reductase Type 1 mutant, mice. Behav Brain Res. 2013;253:232-9. https:// doi.org/10.1016/j.bbr.2013.07.025.

102. Frye CA, Koonce CJ, Walf AA. Progesterone, compared to medroxyprogesterone acetate, to $\mathrm{C} 57 \mathrm{BL} / 6$, but not $5 \alpha$-reductase mutant, mice enhances object recognition and placement memory and is associated with higher BDNF levels in the hippocampus and cortex. Neuroscience Letters. 2013;551:53-7. https://doi.org/ 10.1016/j.neulet.2013.07.002.

103. Koonce CJ, Frye CA. Female mice with deletion of type one $5 \alpha$ reductase have reduced reproductive responding during proestrus and after hormone-priming. Pharmacol Biochem Behav. 2014;122:20-9. https://doi.org/10.1016/j.pbb.2014.03.010.

104. Ford MM, Nickel JD, Kaufman MN, Finn DA. Null mutation of $5 \alpha$-reductase type I gene alters ethanol consumption patterns in a sex-dependent manner. Behav Genet. 2015;45(3):341-53. https:// doi.org/10.1007/s10519-014-9694-2.

105. Ford MM, Nickel JD, Finn DA. Treatment with and withdrawal from finasteride alter ethanol intake patterns in male C57BL/6 J mice: potential role of endogenous neurosteroids? Alcohol. 2005;37:23-33. https://doi.org/10.1016/j.alcohol.2005.11.002.

106. Agis-Balboa RC, Guidotti A, Pinna G. $5 \alpha$-reductase type I expression is downregulated in the prefrontal cortex/Brodmann's area 9
(BA9) of depressed patients. Psychopharmacology. 2014;231: 3569-80. https://doi.org/10.1007/s00213-014-3567-5.

107. Stanczyk FZ, Azen CG, Pike MC. Effect of finasteride on serum levels of androstenedione, testosterone and their $5 \alpha$-reduced metabolites in men at risk for prostate cancer. J Steroid Biochem Mol Biol. 2013;138:10-6.

108. Dubrovsky B. Neurosteroids, neuroactive steroids, and symptoms of affective disorders. Pharmacology Biochemistry and Behavior. 2006;84:644-55. https://doi.org/10.1016/j.pbb.2006.06.016.

109. Frye CA. Progesterone reduces depressive behavior of young ovariectomized, aged progestin receptor knockout, and aged wild type mice in the tail suspension test. J Psychopharmacol. 2011;25(3):421-8. https://doi.org/10.1177/0269881109349836.

110. Frye CA. Endocrine-disruption: elucidating our understanding of their role in sex and gender-relevant end points. Vitamin Horm. 2014;94:41.

111. Frye CA, Paris JJ, Walf AA, Rusconi JC. Effects and mechanisms of $3 \alpha, 5 \alpha$,-THP on emotion, motivation, and reward functions involving pregnane xenobiotic receptor. Front Neurosci. 2012;5: 136. https://doi.org/10.3389/fnins.2011.00136.

112. Rizvi SJ, Kennedy SH, Ravindran LN, Giacobbe P, Eisfeld BS, Mancini D, et al. The relationship between testosterone and sexual function in depressed and healthy men. J Sex Med. 2010;7(2 Pt 1): 816-25. https://doi.org/10.1111/j.1743-6109.2009.01504.x.

113. Majewska MD, Harrison NL, Schwartz RD, Barker JL, Paul SM. Steroid hormone metabolites are barbiturate-like modulators of the GABA receptor. Science. 1986;232(4753):1004-7.

114. Morrow AL, Suzdak PD, Paul SM. Steroid hormone metabolites potentiate GABA receptor-mediated chloride ion flux with nanomolar potency. Eur J Pharmacol. 1987;142(3):483-5.

115. Gee WF, Holtgrewe HL, Albertsen PC, Litwin MS, Manyak MJ, O'leary MP. Painter M.R. Practice trends in the diagnosis and management of prostate cancer in the United States. The Journal of Urology. 1995;154(1):207-8.

116. Brot MD, Akwa Y, Purdy RH, Koob GF, Britton KT. The anxiolytic-like effects of the neurosteroid allopregnanolone: interactions with GABAA receptors. European Journal of Pharmacology. 1997;325(1):1-7.

117. Weir CJ, Ling AT, Belelli D, Wildsmith JA, Peters JA, Lambert JJ. The interaction of anaesthetic steroids with recombinant glycine and GABAA receptors. Br J Anaesth. 2004;92(5):704-11.

118. Qiu M, Lange C. A. MAP kinases couple multiple functions of human progesterone receptors $\mathrm{L}$ degradation, transcriptional synergy, and nuclear association. J Steroid Biochem Mol Biol. $2003 ; 85(2-5): 147-57$.

119. Berretta S, Lange N, Bhattacharyya S, Sebro R, Garces J, Benes FM. Long-term effects of amygdala GABA receptor blockade on specific subpopulations of hippocampal interneurons. Hippocampus. 2004;14(7):876-94. https://doi.org/10.1002/hipo. 20002.

120. Belelli D, Lambert JJ. Neurosteroids: endogenous regulators of the GABA(A) receptor. Nat Rev Neurosci. 2005;6(7):565-75. https:// doi.org/10.1038/nm1703.

121. Skildum A, Faivre E, Lange CA. Progesterone receptors induce cell cycle progression via activation of mitogen-activated protein kinases. Mol Endocrinol. 2005;19(2):327-39.

122. Godar SC, Cadeddu R, Floris G, et al. The steroidogenesis inhibitor finasteride reduces the response to both stressful and rewarding stimuli. Biomolecules. 2019;9(11):749. https://doi.org/10. 3390/biom9110749. This publication shows that rats administered finasteride reduced exploratory incentive, prosocial, and risk taking behavior while decreasing stress coping behaviors. This is concurrent with decreasing CRH MRNA and ACTH levels, suggesting that finasteride impairs stress reactivity and behavioral activation as well as impulsive behavior through the HPA axis. 
123. Kohtz AS, Walf AA, Frye CA. Effects of non-contingent cocaine on 3alpha-androstanediol. I. Disruption of male sexual behavior. Physiol Behav. 2019;203:120-7. https://doi.org/10.1016/j. physbeh.2017.12.017. This publication shows that mating enhanced consummatory but not appetitive sexual behaviors and was associated with levels of 3alpha-androstanediol in the frontal cortex, striatum, and midbrain. Low dosages of cocaine would enhance 3alpha-androstanediol levels in the midbrain; however, medium to high dosages shifted metabolism towards estrogen and disrupted sexual behavior.

124.• Kohtz AS, Walf AA, Frye CA. Effects of non-contingent cocaine on 3 alpha-androstanediol. II. Disruption of lordosis of proestrous rats. Physiol Behav. 2019;203:113-9. https://doi.org/10.1016/j. physbeh.2017.12.016. The results of this paper showed that cocaine administered in low, medium, or high dosages decreased aggressive behavior among diestrus rats and increased aggressive behavior among proestrus rats. Cocaine, dose dependently, altered estradiol and 3alpha-diol but not testosterone, which correlated with aggression, motor behavior, and sexual responses of female rats.

125. Stoner E. The clinical development of a 5 alpha-reductase inhibitor, finasteride. J Steroid Biochem Mol Biol. 1990;37(3):375-8.
126. Frau R, Mosher LJ, Bini V, Pillolla G, Pes R, Saba P, et al. The neurosteroidogenic enzyme $5 \alpha$-reductase modulates the role of D1 dopamine receptors in rat sensorimotor gating. Psychoneuroendocrinology. 2016;63:59-67. https://doi.org/10. 1016/j.psyneuen.2015.09.014.

127.• Kohtz AS, Frye CA. Learning and the lifespan: what's sex got to do with it? Front Neurosci. 2020;14:216. https://doi.org/10.3389/ fnins.2020.00216. This paper shows that exposure to mating relevant stimuli following object recognition training enhances performance in the novel object recognition task. Then, midaged rats that were sexually responsive had better performance in the novel object recognition task when they were presented with the opportunity to mate in the intertrial interval immediately after training compared to sexually unresponsive mid-aged rats. Cognitive performance in the novel object recognition task correlated with 3alpha-diol levels, suggesting its role in mating and cognitive enhancement.

Publisher's Note Springer Nature remains neutral with regard to jurisdictional claims in published maps and institutional affiliations. 